\title{
A Preliminary SPARROW Model of Suspended Sediment for the Conterminous United States
}

Open-File Report 2008-1205 


\section{A Preliminary SPARROW Model of Suspended Sediment for the Conterminous United States}

By Gregory E. Schwarz

National Water-Quality Assessment Program

Open-File Report 2008-1205

U.S. Department of the Interior

U.S. Geological Survey 


\title{
U.S. Department of the Interior DIRK KEMPTHORNE, Secretary
}

\author{
U.S. Geological Survey \\ Mark D. Myers, Director
}

U.S. Geological Survey, Reston, Virginia: 2008

For product and ordering information:

World Wide Web: http://www.usgs.gov/pubprod

Telephone: 1-888-ASK-USGS

For more information on the USGS — the Federal source for science about the Earth, its natural and living resources, natural hazards, and the environment:

World Wide Web: http://www.usgs.gov

Telephone: 1-888-ASK-USGS

Suggested citation:

Schwarz, G.E., 2008, A Preliminary SPARROW model of suspended sediment for the conterminous United States: U.S.

Geological Survey Open-File Report 2008-1205, 8 p., available only online at http://pubs.usgs.gov/of/2008/1205.

Any use of trade, product, or firm names is for descriptive purposes only and does not imply endorsement by the U.S. Government.

Although this report is in the public domain, permission must be secured from the individual copyright owners to reproduce any copyrighted materials contained within this report. 


\section{Contents}

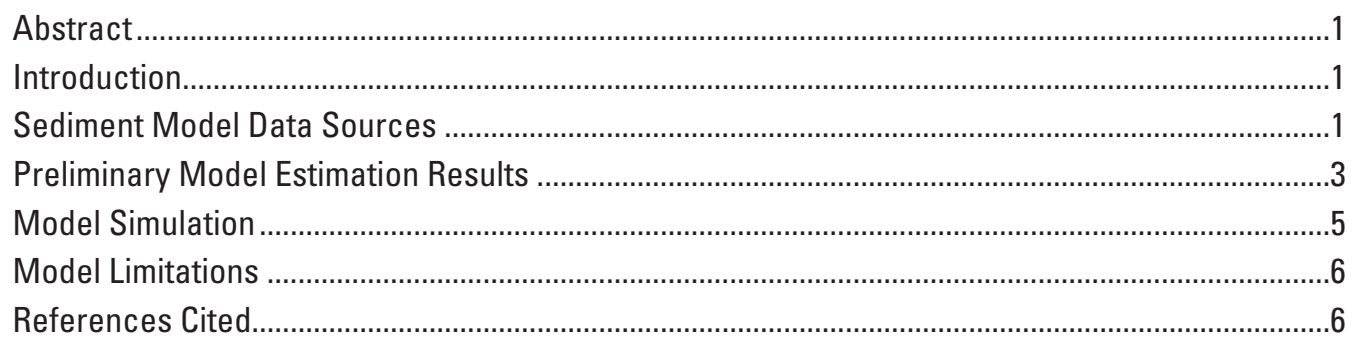

\section{Figures}

1. Location of 1,828 water-quality monitoring stations used in the SPARROW sediment model, in relation to the Reach File 1 (RF1) stream network ......................................................

\section{Tables}

1. Preliminary estimation results for the SPARROW suspended sediment model............................4 


\title{
A Preliminary SPARROW Model of Suspended Sediment for the Conterminous United States
}

\author{
By Gregory E. Schwarz
}

\section{Abstract}

This report describes the results of a preliminary Spatially Referenced Regression on Watershed attributes (SPARROW) model of suspended sediment for the conterminous United States. The analysis is based on flux estimates compiled from more than 1,800 long-term monitoring stations operated by the U.S. Geological Survey (USGS) during the period 1975-2007. The SPARROW model is structured on the Reach File 1 (RF1) stream network, consisting of approximately 62,000 reach segments. The reach network has been modified to include more than 4,000 reservoirs, an important landscape feature affecting the delivery of suspended sediment. The model identifies six sources of sediment, including the stream channel and five classes of land use: urban, forested, Federal nonforested, agricultural and other, noninundated land. The delivery of sediment from landform sources to RF1 streams is mediated by soil permeability, erodibility, slope, and rainfall; streamflow is found to affect the amount of sediment mobilized from the stream channel. The results show agricultural land and the stream channel to be major sources of sediment flux. Per unit area, Federal nonforested and urban lands are the largest landform sediment sources. Reservoirs are identified as major sites for sediment attenuation. This report includes a description for how the model results can be used to assess changes in instream sediment flux and concentration resulting from proposed changes in the regulation of sediment discharge from construction sites.

\section{Introduction}

This report describes the results of a preliminary Spatially Referenced Regression on Watershed attributes (SPARROW) model of suspended sediment for the conterminous United States.

\section{Sediment Model Data Sources}

The spatial framework of the SPARROW sediment model is the vector-based 1:500,000-scale River Reach File (RF)
1 hydrography, originally developed by the U.S. EPA (U.S. Environmental Protection Agency, 1996) and subsequently enhanced to include areal hydraulic load information for selected reservoirs (Ruddy and Hitt, 1990), shoreline reaches, and reach catchment areas derived from the U.S. Geological Survey (USGS) HYDRO1k Digital Elevation Model (DEM) (U.S. Geological Survey, 2006a). The enhanced network (Nolan and others, 2002), consisting of 62,776 reach segments, including shoreline reaches, 61,214 delineated reach catchments, and 2,171 individual reservoirs, has been used to support numerous national SPARROW modeling efforts for the conterminous United States (for example, Alexander and others, 2000). The RF1 reach network for the current SPARROW sediment model was further enhanced by the inclusion of areal hydraulic load information for approximately 2,000 additional large reservoirs (reservoir storage greater than 500 acre-feet), identified from the National Inventory of Dams (NID) (U.S. Army Corps of Engineers, 2006) and linked to the RF1 network according to dam geographic coordinates, river name, and drainage area.

Included in the original RF1 network are reach estimates of mean streamflow and mean velocity, the latter being converted to reach time of travel using the RF1 measure of reach length. The attributes of mean streamflow and mean velocity are used to assess various sediment mobilization and attenuation processes associated with the stream channel. Because catchment areas used to derive the original RF1 estimates of mean streamflow are not compatible with catchments included in the enhanced RF1 network, an alternative measure of mean streamflow was used to compute flow-weighted sediment concentration. The alternative measure is based on an interpolation of USGS streamgage estimates from the 1975-2006 water years (WYs), with extrapolation of streamflow upstream of gages based on runoff estimated at downstream or neighboring stations and apportioned to the land surface according to the enhanced RF1 catchments (David Wolock, U.S. Geological Survey, 2008, written commun.). The available period for these data is 1 year less than the period for this study, and a water year consists of the period October 1st of the previous calendar year through September 30th of the enumerated water year.

The dependent variable in the SPARROW sediment model is given by long-term mean sediment flux. Long-term 
mean sediment flux is estimated using the maximum likelihood approach developed by Cohn (2005), as implemented in the Fluxmaster program (Schwarz and others, 2006). Instream sediment concentrations and stream discharge measurements over the WY period 1975-2007 have been obtained from the National Stream Quality Accounting Network (NASQAN) (Alexander and others, 1996; U.S. Geological Survey, 2006b), the USGS National Water-Quality Assessment (NAWQA) Program (Mueller and Spahr, 2005), and the USGS National Water Information System (NWIS) (U.S. Geological Survey, 2008), a database encompassing USGS water-quality monitoring stations as well as water-quality monitoring activities done in cooperation with State governments. Sampling for suspended sediment (USGS water-quality parameter 80154) is typically done periodically, not daily. Sample data are weighted by channel cross-sectional flow geometry (depth, width) and correlated with stream discharge at the time of sampling. A linear regression model is estimated that relates log-transformed instantaneous suspended-sediment concentration to log-transformed mean daily streamflow, which is measured continuously via water-surface height (stage) coupled with a previously estimated relation between surface height and instantaneous flow. Included in the regression are the sine and cosine of decimal time to capture a seasonal signal, and a linear time trend to be used for detrending flux. To support the detrending of flux, a companion model of daily streamflow is estimated for each water-quality station. The streamflow model relates the logarithm of daily streamflow to a secondorder harmonic of the sine and cosine of decimal time, and a linear time trend term. To account for serial correlation in the daily values, the model is estimated using time-series methods that assume a 30-day autoregression in the residuals. The water-quality and streamflow models are used to simulate daily flux, with both water-quality and streamflow trends removed, for all days within the 33-year period WY 19752007 for which a daily streamflow value is available for every day in the same WY. Thus, if streamflow is not available for any day within a given WY, no simulated water-quality flux is computed for any day in that WY. The simulated estimates of flux, detrended to the base year 1992, for all complete WYs within the 33-year period, are averaged to obtain a detrended flux reflecting long-term mean hydrologic conditions.

The sediment model is estimated using 1,828 monitoring stations located on the RF1 stream network (fig. 1). Stations were selected for inclusion in the model if they had at least 15 concentration measurements during the period WY 1975-2007, and the standard error of the flux estimate did not exceed 80 percent of the flux estimate. Of the stations included in the analysis, 90 percent had streamflow records in excess of 5 years, 70 percent had records exceeding 19 years, and 50 percent had records that exceeded 32 years. Approximately 700 monitoring stations have been indexed to the RF1 stream

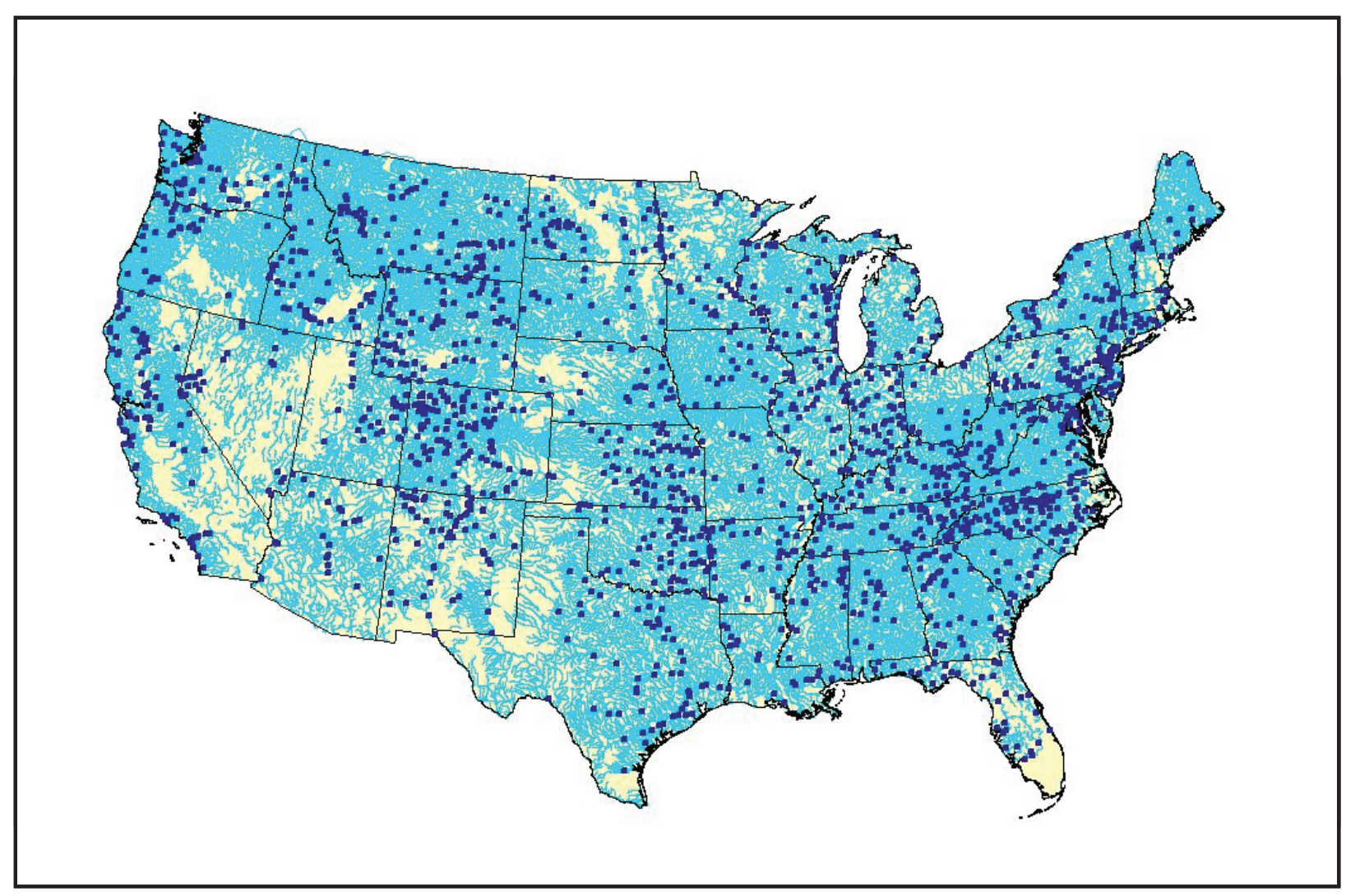

Figure 1. Location of 1,828 water-quality monitoring stations used in the SPARROW sediment model, in relation to the Reach File 1 (RF1) stream network. 
network as part of previous studies (Alexander and others, 2000). The remaining monitoring stations were linked to RF1 reaches via their association with USGS streamgages, which are linked to the National Hydrography Dataset (NHD) reach network (Stewart and others, 2006). The location of these streamgages was transferred from NHD to RF1 using information on streamgage latitude and longitude (based on the NHD location), stream name, and reported drainage area. If multiple stations were present for the same RF1 reach, the alternative stations were first ranked in terms of drainage area, number of days predictions were made, the number of water-quality observations used in estimation, the coefficient of variation of the flux estimate, and whether the water-quality and streamflow records were sufficient to support detrending of flux to the base year. (To be detrended, the water-quality and streamflow records must span at least 3 years and, if extended no more than 15 percent in duration, must include the detrending date June 30, 1992.) The station with the lowest sum of these ranks was selected for inclusion in the model.

Most of the source variables for the SPARROW sediment model are expressed as extensive measures of land use. Data on land cover and land use have been developed from the 2001 USGS National Land Cover Data (NLCD) Set Retrofit Change Product [Multi-resolution Land Characteristics (MRLC), 2001], derived from Landsat Thematic Mapper/Embedded Trace Macrocells (TM/ETM) remotely sensed imagery at 30-meter resolution and classified according to the eight Anderson Level I categories. These data were transformed to 1-square kilometer $\left(\mathrm{km}^{2}\right)$ cells within a Lambert map projection as consistent with HYDRO1k for use within SPARROW. The $1-\mathrm{km}^{2}$ cells are then resolved to catchments associated with specific RF1 reaches. For model estimation, land use was assigned the 1992 values of the 2001 NLCD Retrofit Change Product; the 2001 values of the Retrofit Change Product were used to simulate water-quality conditions for 2001.

Federal nonforested (range and barren) land was included in the model separately from private land. Federal land extent, taken from the Federal Land coverage of the National Atlas (U.S. Geological Survey, 2003) and transformed to $1-\mathrm{km}^{2}$ cells in Lambert projection, was apportioned into Federal range and Federal barren land using the $1-\mathrm{km}^{2}$ transformation of the 1992 NLCD Change Product for Anderson Level I range and barren land classes (see above). For model simulation of 2001 conditions, Federal range and barren land were similarly estimated using the land-use estimates from the 2001 NLCD Retrofit Change Product.

Variables governing the estimated delivery of contaminants from the land to RF1 streams include soil erodibility [the revised universal soil loss equation (RUSLE) K factor], soil permeability (inches/hour; depth integrated), mean slope (percent), and precipitation (RUSLE R factor). Slope, soil erodibility, and permeability were obtained from the State Soil Survey Geographic (STATSGO) database (U.S. Department of Agriculture, 1994), converted to a $1-\mathrm{km}^{2}$ grid in the Lambert projection, and averaged over RF1 catchments. The RUSLE rainfall factor was derived by interpolating a digitized national map of rainfall factor isoline contours (Wischmeier and Smith, 1978), creating a continuous $1-\mathrm{km}^{2}$ grid surface in the Lambert projection. The grid coverage was subsequently averaged over individual RF1 catchments.

\section{Preliminary Model Estimation Results}

The nonlinear, least-squares estimation results of a preliminary version of the SPARROW suspended sediment model are given in table 1 . The preliminary model includes six source terms, five of which are measured by area of specific land use (urban, forested, Federal nonforested, agricultural, and other land, expressed in $\mathrm{km}^{2}$ ), and an additional source given by the length of the stream channel. The Federal land class consists only of Federal range and barren land; it excludes Federal forested land, which is incorporated in the forested land class. Agricultural land includes cropland, pasture land, and orchards. Other land consists of non-Federal range and barren land. Among all the land classes, only wetlands and land covered by water, ice, or snow are excluded as a potential source. The source described as "streambed" relates to stream channels as a direct source of sediment, and is measured in terms of stream length (expressed in meters).

The transport of sediment from the land surface to RF1 rivers is mediated by a land-to-water delivery factor that is expressed as a function (see Equation 1.28 in Schwarz and others, 2006) of logarithm-transformed values of soil permeability, soil erodibility (USLE K factor), land-surface slope, and the USLE rainfall factor. The streambed source is mediated by the logarithm of streamflow, distinguished by streamflows above and below 500 cubic feet per second $\left(\mathrm{ft}^{3} / \mathrm{s}\right)$. Although the mediation of the streambed source by streamflow is not a land process, the manner in which the process is specified in SPARROW is mathematically equivalent to treating streamflow as a land-to-water variable affecting the streambed source, and for this reason streamflow is listed as a land-towater variable in table 1 . To facilitate interpretation of the source coefficients, the delivery variables are all expressed as deviations from their mean value.

Streamflow was used as the mediating factor affecting the mobilization of sediment from the stream channel. There are two principal physical factors affecting the mobilization of sediment from the streambed: the energy of the stream, represented by stream velocity; and the availability of channel material, which is proportional to the area of the streambed per unit of channel length. Direct measurements of channel velocity, width, and depth (the determinants of streambed area per unit channel length) are not available for most reaches in the RF1 network. Streamflow was deemed to be a viable surrogate for these variables because it is highly correlated with them (Schwarz and others, 2006) (in fact, the estimate of velocity included with the RF1 network is derived from streamflow), and because estimates of streamflow exist for all reaches. 
The model specifies two instream sediment-attenuation processes: attenuation in streams (see Equation 1.30 in Schwarz and others, 2006), distinguished by three streamflow classes (less than $500 \mathrm{ft}^{3} / \mathrm{s}, 500-1,000 \mathrm{ft}^{3} / \mathrm{s}$, and greater than $1,000 \mathrm{ft}^{3} / \mathrm{s}$ ); and reservoir attenuation, specified as a function of areal hydraulic load (see Equation 1.34 in Schwarz and others, 2006). The three streamflow classes used to distinguish instream decay are characteristic of the streamflow at the 1,828 monitoring stations: 1,040 stations have streamflow less than $500 \mathrm{ft}^{3} / \mathrm{s}$, and 539 stations have streamflow exceeding $1,000 \mathrm{ft}^{3} / \mathrm{s}$. Attenuation in reservoirs is specified to be a function of the ratio of the reservoir settling velocity, the estimated mean rate at which sediment moves vertically in water, to areal hydraulic load (the ratio of streamflow to reservoir surface area), which represents the velocity a particle at the surface of the stream would need to travel in order to reach the bottom of the reservoir within the average period that the streamflow is impounded in the reservoir.

The estimation results given in table 1 characteristically reflect the large uncertainty associated with sediment model- ing. The model root mean squared error (RMSE) is 1.4, implying that predicted sediment flux or concentration in any given reach has an error of approximately 140 percent (Schwarz and others, 2006). This compares with the much smaller 0.3 RMSE obtained with total nitrogen models (Alexander and others, 2008). Despite this uncertainty, many of the model coefficients are statistically significant. With the exception of forested land, all of the source variables are highly statistically significant. The largest intrinsic sediment yield is associated with Federal range and barren land; urban land has the second highest intrinsic yield. Stream channels are also a statistically significant source of sediment.

Land-to-water delivery for land sources is strongly mediated by the four delivery variables - soil permeability, soil erodibility, slope, and rainfall. As would be expected and with the exception of soil permeability, the presence of higher levels of these factors results in greater sediment delivery to streams. Conversely, permeable soils reduce the delivery of sediment, presumably because more of the water runoff infiltrates into the ground leaving less overland flow to transport

Table 1. Preliminary estimation results for the SPARROW suspended sediment model.

$\left[\mathrm{Kg} / \mathrm{km}^{2} / \mathrm{yr}=\right.$ kilograms per square kilometer per year; $\mathrm{kg} / \mathrm{m} / \mathrm{yr}=$ kilograms per meter per year; $\mathrm{ft}^{3} / \mathrm{s}=$ cubic feet per second; and $\mathrm{m} / \mathrm{yr}=\mathrm{meters} \mathrm{per}$ year]

\begin{tabular}{|c|c|c|c|c|}
\hline Parameter & Units & Estimate & Standard Error & p-value \\
\hline \multicolumn{5}{|l|}{ Source Coefficients } \\
\hline Urban land & $\mathrm{kg} / \mathrm{km}^{2} / \mathrm{yr}$ & 47,130 & 9,925 & 0.000 \\
\hline Forested land & $\mathrm{kg} / \mathrm{km}^{2} / \mathrm{yr}$ & 634 & 898 & 0.480 \\
\hline Federal non-forested land & $\mathrm{kg} / \mathrm{km}^{2} / \mathrm{yr}$ & 64,344 & 12,411 & 0.000 \\
\hline Agricultural land & $\mathrm{kg} / \mathrm{km}^{2} / \mathrm{yr}$ & 18,047 & 3,623 & 0.000 \\
\hline Other land & $\mathrm{kg} / \mathrm{km}^{2} / \mathrm{yr}$ & 11,343 & 3,186 & 0.000 \\
\hline Streambed (reach length) & $\mathrm{kg} / \mathrm{m} / \mathrm{yr}$ & 28.80 & 6.40 & 0.000 \\
\hline \multicolumn{5}{|l|}{ Land-to-Water Delivery Factors } \\
\hline Slope & - & 0.804 & 0.087 & 0.000 \\
\hline Soil permeability & - & -0.778 & 0.094 & 0.000 \\
\hline R-factor & - & 0.821 & 0.081 & 0.000 \\
\hline K-factor & - & 1.292 & 0.279 & 0.000 \\
\hline Flow $\left[<500 \mathrm{ft}^{3} / \mathrm{s}\right]$ (Reach) & - & 0.154 & 0.100 & 0.125 \\
\hline Flow $\left[>500 \mathrm{ft}^{3} / \mathrm{s}\right]($ Reach $)$ & - & 0.721 & 0.354 & 0.042 \\
\hline \multicolumn{5}{|l|}{ Stream Attenuation Factors } \\
\hline Travel time $\left(\mathrm{Q}<500 \mathrm{ft}^{3} / \mathrm{s}\right)$ & day $^{-1}$ & -0.007 & 0.016 & 0.673 \\
\hline Travel time $\left(500<\mathrm{Q}<1,000 \mathrm{ft}^{3} / \mathrm{s}\right)$ & day $^{-1}$ & -0.233 & 0.057 & 0.000 \\
\hline Travel time $\left(\mathrm{Q}>1,000 \mathrm{ft}^{3} / \mathrm{s}\right)$ & day $^{-1}$ & 0.009 & 0.047 & 0.854 \\
\hline Reservoir settling velocity & $\mathrm{m} / \mathrm{yr}$ & 36.49 & 5.552 & 0.000 \\
\hline Number of Observations & 1,828 & & & \\
\hline Root mean squared error (RMSE) & 1.414 & & & \\
\hline R-square & 0.711 & & & \\
\hline
\end{tabular}


sediment. Greater streamflow causes an increase in the amount of sediment generated from stream channels, with the largest effect associated with streams having flows greater than 500 $\mathrm{ft}^{3} / \mathrm{s}$.

Reservoir retention is statistically significant and indicates sediment settles at a mean velocity of 36 meters per year ( $\mathrm{m} / \mathrm{yr})$, comparable to estimates of reservoir attenuation obtained for phosphorus (Alexander and others, 2008). The preliminary model indicates medium-sized streams (flow $500-1,000 \mathrm{ft}^{3} / \mathrm{s}$ ) have a statistically significant negative rate of instream attenuation, indicating that medium streams are a source of sediment, in addition to the stream-channel source identified above. Unlike the streambed source of sediment (see above), which is dictated by channel length and, thus, explicitly tied to a physical entity, the implied "source" of sediment arising from a negative rate of instream attenuation represents a proportional "enhancement" of sediment already suspended in the stream (see Equation 1.30 in Schwarz and others, 2006). Because this proportional enhancement of sediment is not associated with a physical source, it is inconsistent with mass balance and represents an anomalous finding of the model that is not yet explainable. Instream attenuation in small and large streams is not significantly statistically different from zero. Thus, the preliminary model does not find evidence for sediment loss in streams.

\section{Model Simulation}

The estimated SPARROW suspended sediment model for base WY 1992 can be used to simulate water-quality conditions for 2001, with and without U.S. EPA proposed changes in the regulation of construction activity. The simulation of suspended sediment flux for WY 2001, without changes in regulation, is obtained using the model prediction equation, described as Equation 1.120 in Schwarz and others (2006), with all land use-related source variables set to 2001 values according to the 2001 NLCD Retrofit Change Product. Flowweighted average sediment concentration is estimated by dividing simulated flux estimates by mean streamflow over the period WY 1975-2006, obtained from USGS streamgages and interpolated to RF1 reaches (Wolock, U.S. Geological Survey, 2008, written commun.). Although the SPARROW model does not explicitly include a source term for construction, such loading is implicitly accounted for in the urban land component of the model. Therefore, the 2001 precompliance loading from construction (that is, the "base-case" scenario loading) is incorporated in the 2001 loading attributed to urban land that is obtained by evaluating the urban land variable in the SPARROW model using the 2001 NLCD Change Product value.

The absence of an explicit term for construction loading in the SPARROW model necessitates the development of an indirect method for assessing changes in sediment loading arising from different construction industry regulation scenarios. Suspended sediment loading under alternative regulation scenarios has been estimated by U.S. EPA using a variation of the Universal Soil Loss Equation (USLE). The USLE method determines the amount of soil that is mobilized and delivered, under a proposed regulation scenario, to the edge of a construction site. To evaluate the impact that changes in these loadings have on RF1 stream-sediment flux and flowweighted concentration, it is first necessary to assess the rate at which "edge of site" loads are subsequently delivered to RF1 streams. To do this, we use the estimated rate of delivery from agricultural land, a source that is explicitly included in the model, and that can be factored into a mobilization, "edge of site" delivery component and a stream-delivery component. The method described below isolates the stream-delivery component from the overall rate of delivery from agricultural land and applies this component to the change in construction loading to determine the change in loading to RF1 streams. Thus, the approach assumes that the delivery of sediment from the edge of a site to an RF1 stream is the same for both construction and agriculture activities; the mobilization and delivery of sediment to the edge of the site between these activities is allowed to differ. Given that urban areas, as compared to agricultural areas, generally exhibit higher rates of runoff, with compressed runoff duration periods for a given precipitation event, the assumption probably leads to an underestimate in the change in stream-sediment flux from proposed regulation of the construction industry. It would not be necessary to make this assumption if the analysis was based instead on a factorization of urban land delivery; however, as is indicated below, the information necessary to do this is not available.

The amount of sediment mobilized from agricultural land, delivered to the edge of field, and subsequently transported to an RF1 stream, is estimated in SPARROW as the product of the agricultural land-source coefficient and the associated land-to-water delivery factor. This quantity, denoted $K_{\mathrm{AG}}$ and expressed in units of yield as kilograms per square kilometer per year $\left(\mathrm{kg} / \mathrm{km}^{2} / \mathrm{yr}\right)$, is conceptually divided into two components: a component representing the amount of sediment mobilized from agricultural land and delivered to the edge of site, denoted $K_{\text {EOS-AG }}$, and a component representing the fraction of this material that is subsequently delivered to an RF1 stream, denoted $K_{\mathrm{RF}}$. If $\Delta L_{\mathrm{EOS}}(\mathrm{S})$ represents the change in construction sediment loading to the edge of site, as estimated by U.S. EPA using the USLE method, and $\Delta L_{\mathrm{RF} 1}(\mathrm{~S})$ represents the change in sediment loading to RF1 streams associated with construction regulation scenario $\mathrm{S}$, then the two loadings are related according to

$$
\Delta L_{\mathrm{RF} 1}(\mathrm{~S})=K_{\mathrm{RF} 1} \cdot \Delta L_{\mathrm{EOS}}(\mathrm{S})=K_{\mathrm{AG}} \frac{\Delta L_{\mathrm{EOS}}(\mathrm{S})}{K_{\mathrm{EOS}-\mathrm{AG}}}
$$

Given estimates of the regulation-induced change in sediment delivered to each RF1 reach, instream processes associated with attenuation in channels and reservoirs, as described by the SPARROW model estimates, can be applied to estimate changes in sediment flux and concentration for all RF1 reaches. Additionally, because SPARROW imposes 
mass balance, the reservoir attenuation process can be used to assess changes in the amount of sediment retained in each of the approximately 4,000 reservoirs linked directly to the RF1 network.

To implement the method described by Equation 1, it is necessary to have estimates of $K_{\mathrm{AG}}$, the delivery factor for agricultural land, and $K_{\mathrm{EOS}-\mathrm{AG}}$, the amount of soil erosion mobilized from agricultural land and delivered to the edge of site. $K_{\mathrm{AG}}$ is reach specific and is estimated in SPARROW as a function of the land-to-water delivery factors for agriculture (see Equation 1.28 in Schwarz and others, 2006) and the empirically estimated values of the agricultural land-source and land-to-water delivery coefficients. The value for $K_{\mathrm{EOS}-\mathrm{AG}}$ is obtained using information on soil erosion included in the 1992 National Resources Inventory (NRI) (U.S. Department of Agriculture, 1994), which reports county estimates of soil erosion rates for cropland, pasture, and orchards - the land classes encompassed by the class labeled "agricultural land" in the NLCD Retrofit Change Product. ( $K_{\mathrm{RF} 1}$ is based on agricultural land because erosion rates for urban land are not reported by the NRI.) The USLE-based county erosion rates for each of the three land classes were weighted according to the share of county land in the respective class (as reported in the 1992 $\mathrm{NRI}$ ) and then averaged. If there was no county estimate for cropland erosion, an average erosion rate for that county was not computed. The county average erosion rate was apportioned to RF1 catchments according to a $1-\mathrm{km}^{2}$ grid of agricultural land area derived from the 1992 NLCD Retrofit Change Product. For 6,329 catchments where an NRI erosion rate was not available, the erosion rate was estimated by determining an agricultural land weighted average of all available erosion rates for catchments in the same 8-digit hydrologic cataloging unit. Lack of an 8-digit cataloging unit average necessitated using a 6-digit cataloging unit average for 713 catchments, and the remaining 54 catchments were estimated using a 4-digit cataloging unit average.

\section{Model Limitations}

The preliminary SPARROW model for suspended sediment described above has certain limitations, some of which are inherent to the methodology and some the result of the particular model application. An example of the former is the restriction of the analysis to the description of long-term mean water-quality conditions. As explained in Schwarz and others (2006), this restriction is a consequence of imposing mass balance on the predictions. One of the benefits of the mass balance methodology is that it facilitates the interpretation of model coefficients, and enables the comparison of coefficient estimates to estimates obtained by other studies in the literature; however, the restriction to mean water-quality conditions precludes an analysis of the frequency with which conditions of extreme sediment transport occur.
A second example of a methodology-imposed limitation concerns the use of the statistical method to estimate model coefficients. The statistical method provides considerable insight into the evaluation of model fit and the empirical relevance of individual model processes. It also enables the estimation of prediction uncertainty. However, reasonable precision in the statistical estimation of model coefficients is generally possible only if the number of specified model parameters is limited to those associated with sources and delivery processes that have the greatest influence on water quality. The resulting model is parsimonious, but may be overly simplistic in terms of the range of processes affecting sediment transport.

The RF1 reach network is fairly coarse, and its use in the present application limits the ability to predict water-quality conditions in smaller streams. The median headwater catchment area in RF1 is $88 \mathrm{~km}^{2}$, implying water-quality conditions in streams with smaller catchments are unresolved. Additionally, the smallest monitored catchment in the SPARROW sediment model is $13 \mathrm{~km}^{2}$, with only five percent of the monitored catchments less than $100 \mathrm{~km}^{2}$. A SPARROW analysis structured on a denser reach network, such as the National Hydrography Dataset, would relax the reach network limitation, but the large number of reaches associated with this network would make it difficult to conduct a national analysis.

The large error obtained in the present analysis implies the prediction of sediment flux or concentration in any given reach segment is imprecise. Although this error compromises the ability to describe water-quality conditions in any given reach, it does not preclude using the model to characterize water quality in a large grouping of reaches. As long as the error across reaches is sufficiently independent, the assessment of mean water quality in a group of reaches becomes more precise as the size of the group increases.

With the exception of reservoirs, the preliminary model does not find evidence of sediment attenuation in streams. The result implies that sediment transport in streams is not in a steady state. Additional investigation is necessary to determine if this result is real, or if there are additional reach attributes, currently absent from the model, that identify a subset of reaches where sediment attenuation takes place.

\section{References Cited}

Alexander, R.B., Slack, J.R., Ludtke, A.S., Fitzgerald, K.K., Schertz, T.L., Briel, L.I., and Buttleman, K.P., 1996, Data from selected U.S. Geological Survey National Stream Water-Quality Networks (WQN): U.S. Geological Survey Digital Data Series DDS-37, available online at http://pubs.usgs.gov/dds/wqn96cd/. (Accessed January 30, 2008.) 
Alexander R.B., Smith, R.A., and Schwarz, G.E., 2000, Effect of stream channel size on the delivery of nitrogen to the Gulf of Mexico: Nature, v. 403, no. 6771, p. 758-761.

Alexander, R.B., Smith, R.A., Schwarz, G.E., Boyer, E.W., Nolan, J.V., and Brakebill, J.W., 2008, Differences in phosphorus and nitrogen delivery to the Gulf of Mexico from the Mississippi River Basin: Environmental Science \& Technology, v. 42, issue 3, p. 822-830.

Cohn, T.A., 2005, Estimating contaminant loads in rivers-An application of adjusted maximum likelihood to type 1 censored data: Water Resources Research 41:W07003, doi:10.1029/2004WR003833.

Mueller, D.K., and Spahr, N.E., 2005, Water-quality, streamflow, and ancillary sata for nutrients in streams and rivers across the Nation, 1992-2001: U.S. Geological Survey Digital Data Series DDS-152, available online at http://pubs.usgs.gov/ds/2005/152/. (Accessed 1/30/2008.)

Nolan, J.V., Brakebill, J.W., Alexander, R.B., and Schwarz, G.E., 2002, ERF1_2-Enhanced River Reach File 2.0: U.S. Geological Survey OpenFile Report 02-40. (Also available online at http://water.usgs.gov/GIS/metadata/usgswrd/XML/erf1_2. $x m l$.)

Ruddy, B.C., and Hitt, K.J., 1990, Summary of selected characteristics of large reservoirs in the United States and Puerto Rico, 1988: U.S. Geological Survey Open-File Report 90-163.

Schwarz, G.E., Hoos, A.B., Alexander, R.B., and Smith, R.A., 2006, The SPARROW surface water-quality model: Theory, application and user documentation: U.S. Geological Survey Techniques and Methods, section B, chapter 6-B3, 248 p., available only online at http://pubs.usgs.gov/tm/2006/tm6b3/. (Accessed June 10, 2008.)

Steffen, L.J., 1996, A reservoir sedimentation survey information system-RESIS, in Proceedings of the Sixth Federal Interagency Sedimentation Conference, Las Vegas, NV, March 10-14, 1996: Sponsored by the Subcommittee on Sedimentation, Interagency Advisory Committee on Water Data, p. 29-37.

Stewart, D.W., Rea, A.H., and Wolock, D.M., 2006, USGS streamgages linked to the medium resolution NHD: U.S. Geological Survey Data Series DS-195.

U.S. Army Corps of Engineers (USACE), 2006, USACE National Inventory of Dams Web site at http://crunch.tec.army.mil/nidpublic/webpages/nid.cfm. (Accessed June 17, 2005.)
U.S. Department of Agriculture, 1994, State Soil Survey Geographic Data Base: U.S. Department of Agriculture, Soil Conservation Service, National Cooperative Soil Survey, Miscellaneous Publication Number 1492.

U.S. Environmental Protection Agency, 1996, The U.S. Environmental Protection Agency Reach File Version 1.0 (RF1) for the Conterminous United States in BASINS: U.S. Environmental Protection Agency Web page at http://www.epa.gov/waterscience/BASINS/metadata/rfl.htm. (Accessed June 5, 2008.)

U.S. Geological Survey, 2003, Federal lands of the United States, available online at http://nationalatlas.gov/mld/fedlanp.html. (Accessed June 5, 2008.)

U.S. Geological Survey, 2006a, HYDRO1k Documentation, available online at http://edc.usgs.gov/products/elevation/gtopo30/hydro/ readme.html. (Accessed June 5, 2008.)

U.S. Geological Survey, 2006b, National Stream Water Quality Network (NASQAN) Published Data, available online at http://water.usgs.gov/nasqan/data/finaldata.html. (Accessed January 30, 2008.)

U.S. Geological Survey, 2008, USGS Water Data for the Nation, available online at http://waterdata.usgs.gov/nwis. (Accessed February 4, 2008.)

Wischmeier, W.H., and Smith, D.D., 1978, Predicting rainfall erosion losses-A guide to conservation planning: USDA Agriculture Handbook 537, 58 p. 
